\title{
111.3 次元西像の有用性－MR西像とヘリ力ルX線CT西像の比較一 Evaluation of Medical Three Dimensional Image. - Comparion of MR Image and Helical X-ray CT Image.-
}

\begin{abstract}
愛媛大学医学部付属病院放射線部
\end{abstract}

$$
\begin{array}{lll}
\text { 上界幸介 } & \text { 渡部真二 } \\
\text { Kousuke Ueda } & \text { Shinji watanabe } \\
\text { 大元 謙二 } & \text { 川 } \text { 川 壽昭 } \\
\text { Kenji oomoto. Toshiaki Kawakami }
\end{array}
$$

【目的】

デー夕収集方法や処理速度において最近まで非現実的であった 3 次元画像処理も、 M R I の高速シーケンス、X 線 C T Kおけるへリカルスキャンの登場、およびコン ピュータ技術の進歩により現実のものとなりつつある。しかし、現状では 3 次元画 像のみで臨床に使用できるレベルには達しておらず、補助的画像として用いられる 場合が多い。また人体構造をそのまま画像化すると云う理想を考えるならば、2 2 次 元より 3 次元画像の方が優れている事は明白であり、医用画像もその方向に向かう であろう事は容易に予測できる。今回我々は M R I 、 X 線 C T と云う2つ0異なる 画像を比較しながら、3 次元画像の有用性と今後の問題点について検討を行つた。

【方法】

M R I 装置、 X 線 C T 装置各々についてデータ收集、再構成方法、およびアプリ ケーション等について考慮し、3 次元画像における問題点について検討した。画像 については臨床的有用性を重視し視覚的に判断を行った。

\section{【使用機器】}

M R I 装置側

$\mathrm{X}$ 線 C $\mathrm{T}$ 装置側

$$
\begin{aligned}
& \text { 本体 ： G E 社製 } \\
& \text { Work Station: I S G 社製 } \\
& \text { Personal Computer: Apple 社製 Macintosh QD650 } \\
& \text { 本体 : 東芝メティカル社製 Xvigor } \\
& \text { Work Station: 東芝メデイカル社製 X t ension } \\
& \text { Personal Computer: Apple社製 Macintosh LC575 }
\end{aligned}
$$

\section{【結果】}

両者とも基本システムとしては大差はないものと考えるが、、転送速度、記憶容 量、䞘理速度などハードウェアにはまだ多くの解決しなければならない問題を抱え ている。また操作性に大きく影響するユーザースインターフェイスについてもハー ドウェア同様改善の余地が多く残されていると考える。画像については、M R I と $\mathrm{X}$ 線 $\mathrm{C} \mathrm{T}$ は似而非なるものであるが故に単純に優劣を下す事は出来ないが、画像の 解秎の容易さにおいてはX線 C T、情報量では M R I の方が優位であると考えられ た。

\section{【結語】}

3 次元画像は

・形態描出能に優れており、病変の形態、周囲構造 との関係把握が容易である。

・W S (ワークステーション) では大量の画像デー 夕でも連続動態画像として観察可能。

(問題点)

- 間值の設定の良し悪しで 3 次元画像の画質が大き く左右される。

・X線C T では血管壁の石灰化病変も血管内造影剂 とともに描出され、閉塞の判別が困難になる場合 がある。

・画像作成に時間と労力を要する。

- 3 次元画像の評価法、臨床診断学は確立していな い。

(将来への期待)

・手術支援システムへの応用。 シュミレーションシステム ナビゲーションシステムなど。

・画像ファイリングシステムの構筑。

W S を介乙て各種モダリティとのネットワーク

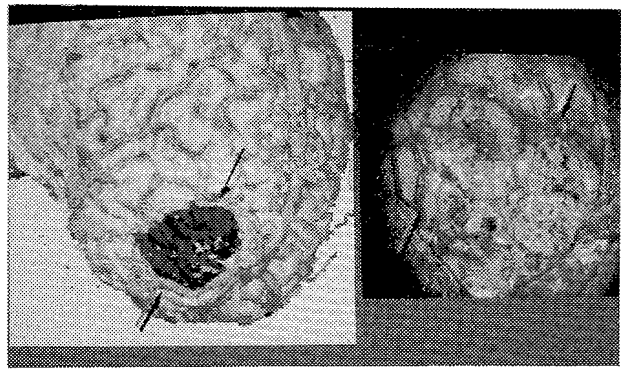

構築。(図下)

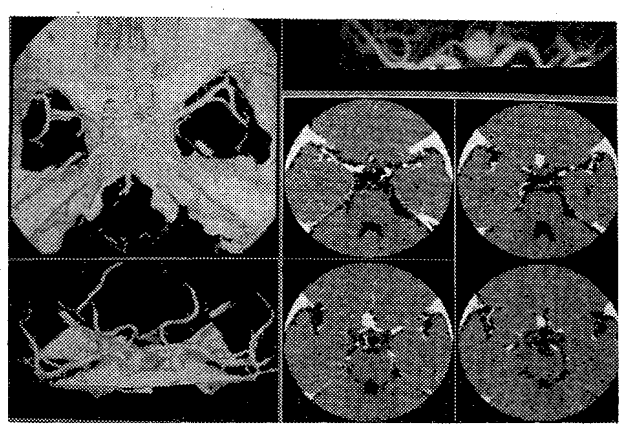

